\title{
Ammonia emission from dairy cow buildings: a review of measurement techniques, influencing factors and possibilities for reduction
}

\author{
G.J. MONTENY ${ }^{1 *}$ AND J.W. ERISMAN ${ }^{2}$ \\ 1 Institute of Agricultural and Environmental Engineering (IMAG-DLO), P.O. Box 43, \\ NL-6700 AA Wageningen, The Netherlands \\ 2 National Institute of Public Health and the Environment (RIVM), P.O. Box 1, \\ NL-3720 BA Bilthoven, The Netherlands (Present address: Netherlands Energy Research \\ Foundation (ECN), P.O. Box 1, NL-1755 ZG Petten, The Netherlands) \\ * Corresponding author (fax.+31 3174256 70; e-mail: g.j.monteny@imag.dlo.nl)
}

Received 9 october 1997; accepted 19 november 1998

\begin{abstract}
Because ammonia from livestock production may contribute substantially to environmental pollution, emission from all possible sources (housing systems, manure storage, manure application, outside grazing) should be reduced. Ammonia emission from dairy cow buildings is estimated to be $28 \%$ of the total emission from Dutch agriculture. The purpose of this study is to make an analytical inventory of ammonia emission data of dairy housing systems and to assess possibilities for its reduction, based upon the analysis of processes and factors involved in the production and volatilisation of ammonia.

Mass balance methods for the determination of air exchange rates for naturally ventilated dairy cow buildings that are based upon natural or introduced tracers may have good potential for application in emission studies.

In today's dairy husbandry, differences occur in housing system, floor type and manure collection and manure storage system. Ammonia emission levels for cubicle (loose) houses are higher (20-45 $\mathrm{g} \mathrm{day}^{-1}$ per cow) than for tie stalls (5-27 $\mathrm{g} \mathrm{day}^{-1}$ per cow), although variation in emissions per housing type is large. Integration of knowledge of ammonia emission related processes and factors will support a more detailed analysis of differences and variation, and will allow an optimisation of possibilities for emission reduction. Substantial emission reductions of up to $50 \%$ for cubicle houses with slatted floors can be achieved through each of the following measures: flushing of floors with water or diluted formaldehyde, optimised feeding strategies, and slurry acidification. Highest reductions are possible through Vshaped, solid floors $(52 \%)$ as a single measure, or in combination with flushing with water $(65 \%)$ or diluted formaldehyde $(80 \%)$. Providing that drawbacks are solved, nation wide introduction of one or more these measures will lead to a maximal reduction of the $\mathrm{NH}_{3}$ emission in The Netherlands with 18 kton per year. To achieve the emission reduction goals set by the Dutch government, additional emission reduction for all agricultural sources must be realised.
\end{abstract}

Keywords: animal nutrition, dairy cattle, environmental pollution, floor construction, legislation, manure treatment, measurement techniques, modelling 


\section{Introduction}

During the past decades, livestock production has been intensified both in numbers of livestock and in production level, following an increased input of minerals through feed stuffs and chemical fertilisers. As a consequence, emission of ammonia $\left(\mathrm{NH}_{3}\right)$ to the atmosphere from livestock production related sources (housing systems, manure storage, land spreading of manure, outside grazing) has increased drastically. The emission of $\mathrm{NH}_{3}$ from agricultural activities in Europe, excluding the former USSR, has doubled between 1950 and 1986 (Asman et al., 1988), whereas for The Netherlands this increase was by a factor 2.5 (ApSimson et al., 1987). This increased $\mathrm{NH}_{3}$ emission has substantially contributed to the exceeding of critical loads for nitrogen $(\mathrm{N})$ deposition in many European countries, leading to eutrophication and soil acidification related environmental stress (Heij \& Schneider, 1991; Heij \& Erisman, 1997).

In The Netherlands, for example, about $46 \%$ of the potential acid deposition is caused by emission of $\mathrm{NH}_{3}$ (Erisman \& Bleeker, 1997), mainly originating from agriculture (Anonymous, 1996). To avoid $\mathrm{NH}_{3}$ related environmental damage, its emission must be reduced with $70 \%$ in 2005 relative to the emission level in 1980 (204 kton; Anonymous, 1996), being the reference year for Dutch $\mathrm{NH}_{3}$ legislation.

In $1995,60 \%$ of the Dutch agricultural $\mathrm{NH}_{3}$ emission originated from cattle husbandry. Ammonia emission from cattle housing systems, including storage, was estimated at 45 kton (37 kton for dairy; 8 kton for other cattle) in 1995, being approximately $34 \%$ ( $28 \%$ for dairy) of the national emission (Anonymous, 1996). In addition to the law enforced advanced slurry application techniques and covering of outside slurry storages, legislation is prepared for animal buildings with low emissions to achieve the reduction goals.

Improved and structured knowledge of $\mathrm{NH}_{3}$ related processes and factors can be used as a tool to improve insight in differences in levels of $\mathrm{NH}_{3}$ emission and to support legislation concerning and research into optimisation of emission abatement strategies for cattle buildings. The availability of accurate methods for measurement of $\mathrm{NH}_{3}$ emissions from agricultural sources is important in the framework national and international emission studies (Asman, 1995; Anonymous, 1994a) and for strategic monitoring and research purposes (e.g. assessment of emission reduction measures). Naturally ventilated animal buildings, being the most common type of dairy cow housing, require in this framework special attention, because of the technical complexity of measurement of its ventilation rates.

The objective of this paper is a literature-based discussion on the origin of $\mathrm{NH}_{3}$ release in dairy cow buildings and possibilities for measurement and abatement of $\mathrm{NH}_{3}$ emissions. In this perspective the following issues are addressed:

- theory of $\mathrm{NH}_{3}$ development in dairy cow buildings

- state of the art in measurement technology for animal buildings

- inventory of current housing systems for dairy cows and their $\mathrm{NH}_{3}$ emissions

- possibilities for reduction of $\mathrm{NH}_{3}$ emission based upon the way they interfere with emission related processes and factors

- synthesis and conclusions. 


\title{
Processes and parameters influencing $\mathrm{NH}_{3}$ release in dairy cow buildings
}

\author{
$N$ excretion in faeces and urine
}

Nitrogen plays a basic role in the life cycle, physiological processes, production and body maintenance of animals. All $\mathrm{N}$ that is taken up with the feed and not retained in the animal body is excreted in faeces and urine. Tamminga (1992) estimated that, of the daily $\mathrm{N}$ intake by an average Dutch dairy cow, $29 \%$ is excreted in faeces, $50 \%$ in urine and $19 \%$ in milk, while $2 \%$ was deposited in body reserves. Non-protein $\mathrm{N}$ compounds, mainly being in the form of urea, are excreted with urine. Ammonia in dairy cow buildings is for the largest part produced following urea hydrolysis (Muck $\&$ Steenhuis, 1981). The amount of urea $\mathrm{N}$ relative to the total $\mathrm{N}$ content of dairy cow urine depends on physiological factors like diet composition and production level and is between 59-89\% for cattle fed with grass or grass and maize silage, including protein supplement (Bristow et al., 1992). An increasing surplus of degradable protein in the diet will result in a higher rate of $\mathrm{N}$ excretion with urine (Van Vuuren et al., 1993), whereas the volume of urine produced is related to the intake of $\mathrm{N}$, potassium (K) and sodium (Na) (Van Vuuren \& Smits, 1997). This volume will affect the urination frequency. Whitehead (1995) made an inventory of urine production (volume, urination frequency) by dairy cows and of typical values for faecal and urinary $\mathrm{N}$ excretion. In this inventory, covering many international literature sources, it is discussed that all parameters mentioned above show a large variation, mainly related to differences in diet (including water consumption), production level, breed and management. Urine production, urination frequency, urea $\mathrm{N}$ concentration in urine and $\mathrm{N}$ excretion with urine, expressed per cow, range from 10-40 1 day $^{-1}, 8-12$ day $^{-1}, 2-20 \mathrm{~g} \mathrm{l}^{-1}$ and $80-320 \mathrm{~g} \mathrm{day}^{-1}$, respectively. Faeces mainly contain organic $\mathrm{N}$ compounds (e.g. undigested protein; daily N excretion 50-200 g per cow). Ammonia production from these compounds in dairy cow buildings is relatively unimportant (Muck \& Steenhuis, 1982), because of low mineralisation rates. Mineralisation may play a role when the slurry is stored, either inside or outside the house, for longer periods of time and especially at higher temperatures (Patni \& Jui, 1991).

\section{Urea hydrolysis}

Urea hydrolysis, catalysed by the enzyme urease, follows the Michaels Menten kinetics for basic enzymatic conversion processes (see e.g. Muck \& Steenhuis, 1981). Urease is produced by micro organisms that are abundantly present in faeces and thus also upon surfaces that are frequently fouled with faeces, like floors (Ketelaars \& Rap, 1994). The following equation represents urea hydrolysis in a liquid environment (e.g. urine on the floor, urine in the straw bed or slurry in the pit):

$$
\mathrm{CO}\left(\mathrm{NH}_{2}\right)_{2}+\mathrm{H}_{2} \mathrm{O} \stackrel{\text { urease }}{\longrightarrow} 2 \mathrm{NH}_{3}+\mathrm{CO}_{2}
$$

The rate of urea hydrolysis and thus the ammonium production rate depends on the urea concentration in the urine and the maximal rate of enzymatic urea hydrolysis at 
high urea concentrations, also called 'urease activity'. Urease activity is temperature related. Muck \& Steenhuis (1981) reported complete urea conversion within 1 day after urine deposition upon fouled floors at temperatures above freezing point. Furthermore, Elzing \& Monteny (1997a) showed that all urea in urine applied on a fouled slatted floor element was converted within approximately two hours at temperatures of $10{ }^{\circ} \mathrm{C}$ or higher. This means that urea hydrolysis is completed fast under conditions found in practice. Moreover, urease activity levels in commercial dairy cow buildings are very high (Braam \& Van Den Hoorn, 1996), making the substrate (urea) availability the limiting factor. Measures that reduce emissions from fouled floors may therefore focus on lowering the initial urea concentration in the urine via nutrition or very frequent dilution (e.g. by flushing floors with water) or on a drastic reduction of the urease activity.

\section{Dissociation}

In the liquid, ionised (ammonium; $\mathrm{NH}_{4}^{+}$) and unionised (ammonia; $\mathrm{NH}_{3}$ ) equilibrilize (equation 2):

$$
\mathrm{NH}_{3}+\mathrm{H}_{2} \mathrm{O} \stackrel{\mathrm{pH}, \mathrm{T}}{\longrightarrow} \mathrm{NH}_{4}^{+}+\mathrm{OH}^{-}
$$

The amount of $\mathrm{NH}_{3}$ relative to total ammoniacal $\mathrm{N}$ (TAN: sum of $\mathrm{NH}_{3}$ and $\mathrm{NH}_{4}^{+}$) in the liquid is determined by the, positively with temperature (' $\mathrm{T}$ ') related, acid dissociation constant $\left(\mathrm{K}_{\mathrm{a}}\right)$ for $\mathrm{NH}_{3}$ and by the $\mathrm{pH}$ (Loehr, 1973). For $\mathrm{NH}_{3}$ dissociation in aqueous solutions at $20^{\circ} \mathrm{C}, \mathrm{K}_{\mathrm{a}}$ is $3.982 * 10^{-10}$ (Weast et al., 1986), whereas for more concentrated solutions, like slurries, an adapted - much lower $-\mathrm{K}_{\mathrm{a}}$-value was found $\left(0.81 * 10^{-10}\right.$; Hashimoto, 1972$)$. The influence of $\mathrm{pH}$ is very pronounced. At $\mathrm{pH}$ values below 6-7, nearly all TAN in the liquid is present in ionised, non-volatile form $\left(\mathrm{NH}_{4}^{+}\right)$. Above $\mathrm{pH} 7$, the fraction of $\mathrm{NH}_{3}$ increases greatly and at $\mathrm{pH}$ values of 11 or higher TAN is mainly in the form of $\mathrm{NH}_{3}$. Data reported by Elzing \& Monteny (1997a) showed that the urine on a fouled floor has a $\mathrm{pH}$ of around 8.6, whereas that value was also assumed for the $\mathrm{pH}$ of the top layer of slurry in the pit, being the places where volatilisation takes place. At these $\mathrm{pH}$ levels, up to $50 \%$ of TAN is present in the form of volatile $\mathrm{NH}_{3}$ (Groot Koerkamp \& Elzing, 1996), mainly depending on temperature. Acidification of slurry and urine to a level of below pH 6 is a very effective way to lower the $\mathrm{NH}_{3}$ release.

\section{Volatilisation}

Volatilisation of $\mathrm{NH}_{3}$ is convective mass transfer from the boundary of urine or slurry and air to the air above the floor or above the slurry in the pit. The amount of volatile $\mathrm{NH}_{3}$ depends on equilibrium between $\mathrm{NH}_{3}$ in the liquid ('l') and in the gas phase ('g') at that boundary (equation 3), following Henry's Law:

$$
\mathrm{NH}_{3}(\mathrm{l}) \stackrel{\mathrm{T}}{\longrightarrow} \mathrm{NH}_{3}(\mathrm{~g})
$$


This equilibrium is strictly temperature dependent; higher temperatures result in a higher amount of gaseous $\mathrm{NH}_{3}$.

Ammonia volatilisation rate (equation 4) is the product of the $\mathrm{NH}_{3}$ mass transfer coefficient and the difference in concentration or partial pressure of gaseous $\mathrm{NH}_{3}$ (' $\mathrm{g}$ ') between boundary ('bound') and air above the boundary ('air').

$$
\mathrm{NH}_{3}(\mathrm{~g}, \text { bound }) \stackrel{\mathrm{T}, v}{\longrightarrow} \mathrm{NH}_{3}(\mathrm{~g} \text {, air })
$$

The mass transfer coefficient for $\mathrm{NH}_{3}$ depends on temperature (' $\mathrm{T}$ ') and air velocity ('v') at the boundary. Haslam et al. (1924) developed a general relationship for $\mathrm{NH}_{3}$ in a film reactor. It was found to be applicable for dairy cow housing systems too (Muck \& Steenhuis, 1981). More empirically determined mass transfer coefficients for $\mathrm{NH}_{3}$ in the framework of animal husbandry emissions research were reported in recent studies (Svensson \& Ferm 1993; Arogo et al., 1996), but their application was not studied for other conditions and situations than that they were developed for.

Elzing \& Monteny (1997a) showed that, at values for urease activities found in dairy cow buildings, $\mathrm{NH}_{3}$ volatilisation is the highest at approximately two hours after urine deposition upon floors. Furthermore, $\mathrm{NH}_{3}$ volatilisation from a urine puddle was found to continue for 15 hours or more, depending on environmental conditions. Interfering in the volatilisation process itself to reduce $\mathrm{NH}_{3}$ release in dairy cow buildings will have to focus on reducing temperature, through cooling of floor and slurry surfaces, and air velocity, by minimisation of airflow inside the building.

\section{Measurement techniques for $\mathrm{NH}_{3}$ emission from livestock buildings}

The emission of $\mathrm{NH}_{3}$ from a building is defined as the product of air exchange rate and the difference in $\mathrm{NH}_{3}$ concentrations in incoming and exhaust air. Methods and equipment for measurement of air exchange rates and gas concentrations are discussed below.

\section{Air exchange rates}

Direct methods. For mechanically ventilated animal buildings, the anemometer or measurement ventilator installed in the ventilation shaft (Van Ouwerkerk, 1993) is commonly used to determine air exchange rates directly. Wind tunnel calibration is necessary to relate the anemometer response (rotations per time unit) with the actual air exchange rate.

Continuous monitoring of pressure differences over all ventilation openings of the building is useful as a direct method for naturally ventilated animal buildings. The basis of this method is Bernoulli's Law, relating the ventilation rate over an opening to the surface area of the opening and the square root of the pressure difference over the opening (Van Ouwerkerk, 1993). It is still in an experimental stage.

Indirect methods. Indirect methods, using heat balances or tracer gas mass bal- 
ances, have become ready for use during the past years. The basic principle of the heat balance method (Van 't Ooster et al. ,1994; Van Ouwerkerk, 1993) is that the change in temperature of the air volume inside the building is the net result of heat production (e.g. by animals or external heating) and heat losses, mainly through convective heat transfer through the structure, and ventilation. To calculate ventilation rate, all other heat production and loss terms have to be known. Ventilation rate for a certain time step directly follows from measured change in air temperature inside the building per time unit, given the effective heat capacity of the air inside the building.

The principle of mass balance methods for tracer gasses is basically the same as for the heat balance approach. The ventilation rate follows from the net result of tracer gas production and losses, assuming no gas transport through the construction elements of the house. Depending on the goal of the measurements, methods for natural and synthetic tracer gases are:

- a variable, known production rate, e.g. when production rate from the source of the tracer gas cannot be controlled (natural tracer gas)

- a constant production rate (continuous dosage of a synthetic tracer gas)

- rate of decay (certain amount of synthetic tracer gas introduced in the house at $\mathrm{t}=0$ )

In the framework of emission surveys, continuous determination of the ventilation rate is required. This makes the first two methods the most appropriate. In Van Ouwerkerk (1993), a detailed description is given of the variable production rate method using the $\mathrm{CO}_{2}$ mass balance. This method requires a $\mathrm{CO}_{2}$ production model for animals (Van Ouwerkerk \& Pedersen, 1994). Introduced tracer gases like carbon monoxide (CO; Demmers et al., 1998), sulphur hexa fluoride $\left(\mathrm{SF}_{6}\right)$ and nitrous oxide $\left(\mathrm{N}_{2} \mathrm{O}\right)$ can be used in the method of constant production rate.

\section{Measurement equipment for gas concentrations}

Tracer gases. Van 't Klooster et al. (1996) give an overview of technical possibilities for the measurement of tracer gas concentrations in the framework of $\mathrm{NH}_{3}$ emission studies. For the purpose of accurate measurement of emission levels or process studies, $\mathrm{N}_{2} \mathrm{O}, \mathrm{CO}$ and $\mathrm{CO}_{2}$ concentration can be measured best with monitors based upon the Non Dispersive Infra Red principle (NDIR). Basic elements of such monitors are an infrared emitter and receiver. Different gasses show absorption of specific wavelengths in the IR spectrum. The measured absorption or extinction in the IRspectrum is a direct measure for the concentration of the gas under survey. They can be used for specific gases (Demmers et al., 1998), when using the appropriate filters, or for multi gas measurements (Van Ouwerkerk, 1993). Cross sensitivity with e.g. water vapour may affect measurement accuracy. When $\mathrm{SF}_{6}$ is used, concentrations need to be measured with a gas chromatograph (GC).

Ammonia. Besides NDIR monitors, a nitrogen oxide (NO) monitor in combination with a high temperature catalyst stainless steel converter is commonly used in The Netherlands for continuous measurement of $\mathrm{NH}_{3}$ concentrations in livestock buildings. This method is described in detail by Van Ouwerkerk (1993) and Groot Koer- 
kamp et al. (1998). In the catalyst converter, $\mathrm{NH}_{3}$ is converted to NO. The main reason for this is that $\mathrm{NO}$ is reasonably inert, while $\mathrm{NH}_{3}$ in the air sampling tubes may be lost e.g. by dissolving in water drops or absorption at the tube surface. NO monitors use the principle of a chemo-luminescence reaction between $\mathrm{NO}$ and ozone. Wyers et al. (1993) describe the development and application of a continuous flow denuder for $\mathrm{NH}_{3}$ concentration studies, basically for ambient $\mathrm{NH}_{3}$ concentration levels but also for a wider application (e.g. in livestock buildings; Van Ouwerkerk, 1993). It has a much lower detection limit than the measurement techniques described previously. The basic process in a denuder is chemical absorption/desorption using counter flows of sampled air and acid absorption solutions. After a desorption procedure, the $\mathrm{NH}_{3}$ concentration is measured on-line conductometrically.

When continuous measurement of $\mathrm{NH}_{3}$ concentration is not required, a system of continuous air sampling and accumulation in an acid solution (e.g. nitric acid) in combination with titrimetric determination of the amount of $\mathrm{NH}_{3}$ captured afterwards in a laboratory or accumulation in passive samplers can be used (Van Ouwerkerk, 1993).

\section{Evaluation}

The advantage of the heat balance is the fact that only the air temperature inside the building has to be measured, which is fairly simple compared to measurement of tracer gasses concentrations. Drawbacks are related to the need for models to predict heat production terms (animals) and losses through the surrounding structure.

Assuming no gas transport through the structure, advantages of the use of tracer gasses lie in the limited number of loss terms, since this can only be through ventilation (assuming no accumulation in manure, the animal or parts of the internal structure). On the other hand, the density of the tracer gas should be close to air density to allow the assumption of perfect mixing. When using the $\mathrm{CO}_{2}$ mass balance, no tracer gas has to be introduced in the building, meaning that the measurement system can be restricted to gas sampling and analysis only. When synthetic tracer gasses are used, a dosage system has to be installed and operated. Moreover, synthetic tracer gasses may have other drawbacks like toxity (CO), specific masses differing from air $\left(\mathrm{N}_{2} \mathrm{O}, \mathrm{CO}\right)$ and the possibility of gas production from unknown or unexpected sources $\left(\mathrm{N}_{2} \mathrm{O}\right.$; nitrification/denitrification of nitrogen compounds).

Scholtens et al. (1996) validated the use of $\mathrm{CO}_{2}$ and $\mathrm{CO}$ mass balance methods against the method of anemometers placed in the exhaust shafts in a mechanically ventilated dairy cow building. The $\mathrm{CO}_{2}$ method underestimated the ventilation rate by $18 \%$, whereas the $\mathrm{CO}$ method showed no significant difference with the anemometer method. The model for $\mathrm{CO}_{2}$ production by the animals (Van Ouwerkerk \& Pedersen, 1994) was found to be the most important source of the underestimation by using the $\mathrm{CO}_{2}$ mass balance (Scholtens et al., 1996). Van Ouwerkerk \& Pedersen (1994) proposed to increase the respiration quotient to improve the $\mathrm{CO}_{2}$ production model for dairy cows. Demmers et al. (1998) showed that applicability of the CO mass balance is quite good, except under conditions of high ventilation rates in naturally ventilated buildings. Under these conditions, mainly caused by high outside 
wind speeds, the difference in $\mathrm{CO}$ concentrations between air entering and leaving the building appeared to be too small to be measured accurately and thus to allow accurate estimation of the ventilation rate.

For continuous and exact measurement of $\mathrm{NH}_{3}$ emissions from mechanically ventilated buildings, an anemometer in combination with the converter + NO monitor or with a NDIR monitor is to be preferred, whereas the combination of synthetic tracer gas and specific monitors or a GC is the best procedure for naturally ventilated buildings.

Besides methodology and measurement technique, measurement strategy (design of hardware and protocol for measurements) is of great importance when carrying out emission studies for naturally ventilated cow buildings. Incomplete mixing of volumes of air inside the house leads to spatial variability in gas concentrations. This aspect has to be studied before the measurements start in order to design the sampling system (number and location of sampling points) for air inside the house correctly. When designing the protocol for measurements, detailed knowledge of the emission process benefits minimisation of the number of measurements and its duration. Mechanistic modelling of the processes relevant for $\mathrm{NH}_{3}$ emission (Muck \& Steenhuis, 1981; Monteny et al., 1998) and the application of statistics (De Boer, 1993) may contribute to this.

\section{Dairy cow buildings: floor and manure handling systems and $\mathrm{NH}_{3}$ emission}

Two main types of housing systems for dairy cows can be distinguished: loose housing and tie stalls. In loose housing, the two major sub-systems are cubicle housing systems and non-cubicle or (deep) litter and straw systems. Functional elements of loose housing systems are a non-restricted (open, straw bed) or partly restricted (cubicles) lying area, a walking area and a feeding area. For tie stalls systems, these functional elements are combined (Anonymous, 1994b). Floor type, manure handling and indoor manure storage facilities are the major characteristics that are relevant from $\mathrm{NH}_{3}$ emission point of view. Table 1 presents an overview of dairy cow housing systems, subdivided by these characteristics. Except for straw based systems where farmyard manure (FYM) is produced, manure is present in the form of slurry. Ammonia emission data are given to the extent that reliable data were available from different literature sources. Conditions under which the measurements were carried out (ventilation system and measurement principle of ventilation rate) are reported. Data are discussed in the following paragraphs.

\section{Loose housing systems}

Cubicle houses with slatted floors are the most common for dairy cows in The Netherlands (Anonymous, 1995) and some other European countries (Anonymous, 1994a). Inside, under floor pits are present for slurry storage. Kroodsma et al. 
AMMONIA EMISSION FROM DAIRY COW BUILDINGS

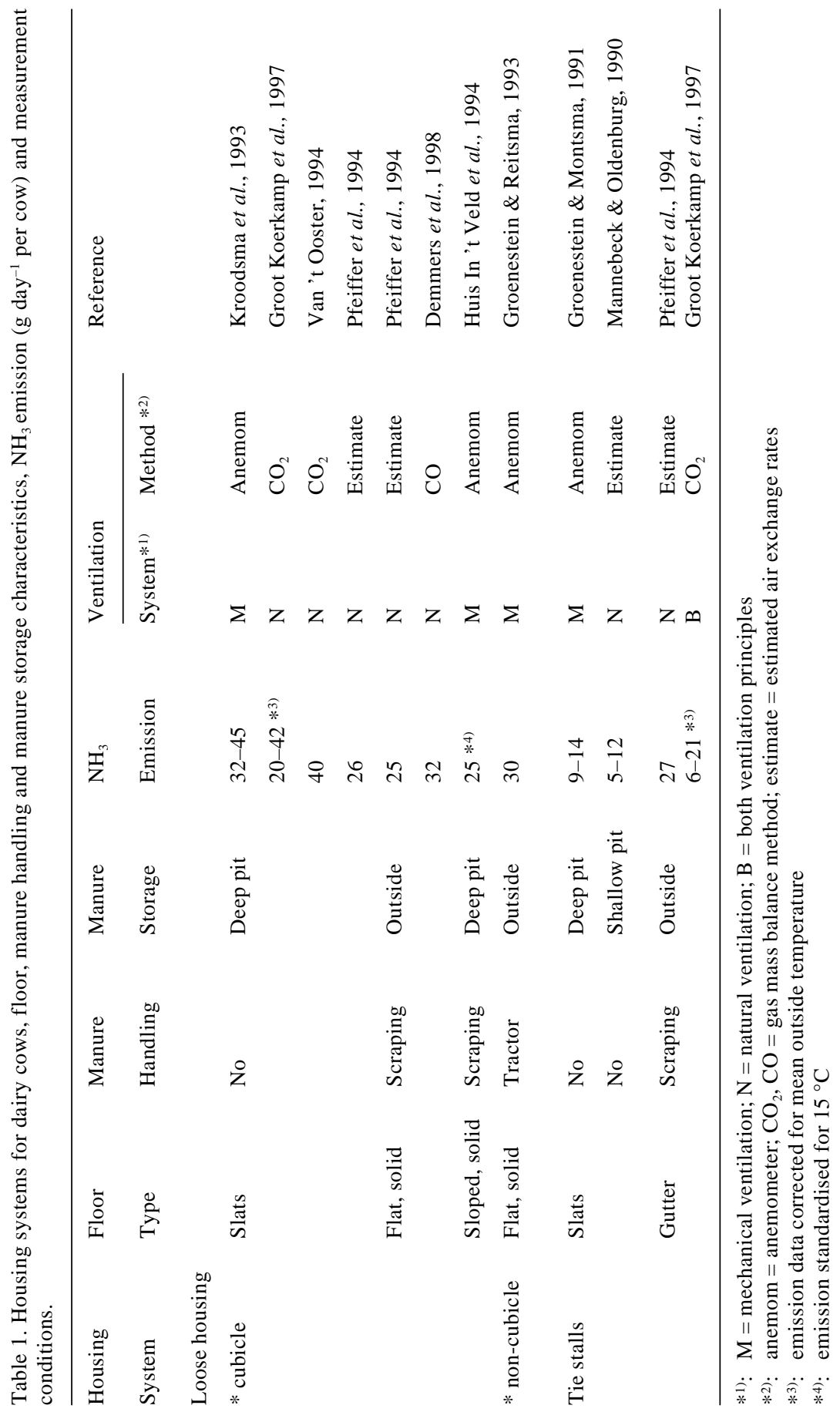


(1993) found $\mathrm{NH}_{3}$ emission from a mechanically ventilated cubicle house varying from 32 to $45 \mathrm{~g}$ day ${ }^{-1}$ per cow at an inside air temperature range of 12 to $18{ }^{\circ} \mathrm{C}$. Groot Koerkamp et al. (1997) measured $\mathrm{NH}_{3}$ emissions from 16 cubicle dairy cow buildings during a large survey in 4 European countries (UK, The Netherlands, Denmark and Germany). Ammonia emission was measured during $24 \mathrm{~h}$ under winter and summer conditions. After correction for mean outside temperature, average $\mathrm{NH}_{3}$ emission per country ranged from 20 (Denmark) to 42 (The Netherlands) g day ${ }^{-1}$ per cow. The observed variation between 4 similar dairy cow buildings per country and between countries can be regarded as a combination of systematic and natural variation, mainly caused by differences in climate, diets, details in the building designs and management. Other emission data for naturally ventilated cubicle buildings with slurry storage beneath the slatted floor were found to amount $40 \mathrm{~g} \mathrm{day}^{-1}$ per cow (Van 't Ooster, 1994) and $26 \mathrm{~g} \mathrm{day}^{-1}$ per cow (Pfeiffer et al., 1994). Emission data were not corrected for temperature.

Inclined shallow pits beneath the slats are common for cubicle houses in the US (Collins \& Wilson, 1994). In these systems, slurry is continuously removed from the house by gravity and stored outside, e.g. in a slurry lagoon. Emission data in literature were lacking for such housing systems.

Cubicle housing systems with flat or sloped solid floors are found in various countries. A solid floor type implies that faeces and urine have to be removed regularly (e.g. with scrapers) and collected in an under floor pit or in an outside storage. When a flat solid floor is present, there may be a longitudinal incline towards a dorsally situated collection gutter to allow slurry removal by flushing and additional outside storage (e.g. in a lagoon; Fulhage \& Martin, 1994). Ammonia emission levels for cubicle houses with flat solid floors with scrapers and outside slurry storage of 24.5 and 31.6 g day ${ }^{-1}$ per cow were reported by Pfeiffer et al. (1994) and Demmers et al. (1998), respectively. Data were not corrected for temperatures. Sloped, solid floors may be designed V-shaped, with a lateral slope, so urine is drained through a small gutter, longitudinally situated in the middle of the floor (Swierstra et al., 1995). The slope may also be to one of the sides of the walking alley (Moore \& Hegg, 1980). Ammonia emission for a V-shaped solid floor with a $3 \%$ lateral slope was $24.5 \mathrm{~g} \mathrm{day}^{-1}$ per cow, corrected for a reference temperature of $15^{\circ} \mathrm{C}$ (Huis in 't Veld et al., 1994).

Non-cubicle loose housing systems, operated with a straw bed or a concrete floor, are less common than loose housing systems with cubicles. When a straw bed is used, faeces and urine collected often remain in the house for a longer period of time. Removal of the collected faeces and urine - indicated as farm yard manure (FYM) - can be by hand or by a scraper attached to a tractor. Ammonia emission for a mechanically ventilated house containing 40 dairy cows and 18 head of young stock, at an average temperature of $9{ }^{\circ} \mathrm{C}$, was on average $30 \mathrm{~g} \mathrm{day}^{-1}$ per animal (not corrected for temperature; Groenestein \& Reitsma, 1993).

Tie stalls

In tie stalls, faeces and urine are collected either as slurry in an under floor pit cov- 
ered with concrete or steel slats, or in a shallow gutter where faeces and urine are separately collected. In the US, tie stalls are often equipped with inclined shallow pits beneath the slats (Graves et al., 1984). Removal of the faeces, optionally collected in a layer of straw in the gutter (FYM), is carried out by hand or by a scraper, whereas urine is drained off by gravity. FYM is usually stored outside. Daily $\mathrm{NH}_{3}$ emission for a commercially operated, mechanically ventilated tie stall for dairy cows, with slurry storage in a pit with a depth of $1 \mathrm{~m}$ behind the animals, varied with temperature ( 15 to $19^{\circ} \mathrm{C}$ ) from 9 to $14 \mathrm{~g}$ per cow (Groenestein \& Montsma, 1991). Ammonia emission from 16 naturally and mechanically ventilated tie stalls, observed in 4 European countries in the framework of the international survey described previously, varied from 6 to $21 \mathrm{~g} \mathrm{day}^{-1}$ per cow (corrected for mean outside temperature) (Groot Koerkamp et al., 1997). Based upon an estimated ventilation rate, Mannebeck \& Oldenburg (1990) and Pfeiffer et al. (1994) reported emissions of 5 to $27 \mathrm{~g} \mathrm{NH}_{3}$ day $^{-1}$ per cow (not corrected for temperature) for a large number of naturally ventilated tie stalls, measured under various outside temperatures. As described for emissions from cubicle housing systems, ranges in $\mathrm{NH}_{3}$ emission from tie stalls observed appear to be large due to systematic and natural variation in emission determining factors.

\section{Measures to reduce $\mathrm{NH}_{3}$ emission from dairy cow buildings}

Measures that reduce the $\mathrm{NH}_{3}$ emission from a dairy cow house are based on engineering, nutrition or management. They influence one or more of the parameters that play a role in the emission related processes. Main themes are: (1) reduction of the urea concentration of urine by nutritional measures; (2) dilution of urine on floors and removal from floors; (3) slowing down the urea hydrolysis on floors; (4) control of $\mathrm{pH}$; (5) reduction of mass transfer of $\mathrm{NH}_{3}$ from urine and slurry; and (6) reduction of air exchange between pit and house.

\section{Reduction of the urea concentration of urine by nutritional measures}

Altering the diet is regarded as an effective and direct way of achieving a reduction of the urea concentration in the urine. Smits et al. (1995) compared the effect on the $\mathrm{NH}_{3}$ emission of two diets in a commercial cubicle house with 34 lactating, highly yielding dairy cows in a repetitive experiment over 126 days. The diets differed in nitrogen content, resulting in a daily intake per cow of rumen degradable protein (RDP) with the "low-N" diet of $40 \mathrm{~g}$, and of $1060 \mathrm{~g}$ with the "high-N" diet. Salt was added to the low- $\mathrm{N}$ diet to obtain similar urine production volumes. As a result, the concentration of urea nitrogen for the low-N diet was $42 \%$ lower than for the high-N diet, whereas the emission of $\mathrm{NH}_{3}$ was reduced with approximately $39 \%$. The results are in good accordance with the findings by Elzing \& Monteny (1997b). They reported a linear relation between the urea concentration and the $\mathrm{NH}_{3}$ emissions in trials, conducted in a scale model of a dairy cow house, where a fouled slatted floor element was sprinkled with urine from groups of lactating cows fed with different 
diets. In another experiment (Smits et al., 1997) similar to the one mentioned previously (Smits et al., 1995), salt was added to the high-N diet to increase both $\mathrm{N}$ excretion in urine and urine production, at a comparable urinary urea concentration. The emission reduction by the low-N diet was approximately $20 \%$, mainly caused by the reduced number of urinations per cow.

\section{Dilution and removal of urine on floors}

Indirect lowering of the urea and TAN concentration is achieved through flushing floors. Adding water results in a dilution of the urine on the floor and of the slurry in the pit. Besides dilution, removal of urine from the floor surface is a feature of flushing systems. The frequency of the flushing actions and the amount of water used per flushing determine the potential $\mathrm{NH}_{3}$ emission reduction. Frequent flushing results in more frequent removal of urine, whereas flushing with more water results in an increased dilution.

By flushing slatted floors, $\mathrm{NH}_{3}$ emission was reduced by a maximum of $17 \%$ (De Boer et al. ,1994; Ogink \& Kroodsma, 1996). Even though different amounts of water (up to 1101 day $^{-1}$ per cow) and flushing intervals (once every $1-3.5 \mathrm{~h}$ ) were used, no relationship was found between emission reduction and those variables. Relative to unflushed slatted floors, spraying a V-shaped solid floor with 61 of water day ${ }^{-1}$ per cow at a scraping and flushing frequency of once every two hours resulted in a $65 \%$ reduction of the $\mathrm{NH}_{3}$ emission (Braam et al., 1997b). The effects of amounts of water used and flushing and scraping frequencies on the emission reduction for a $\mathrm{V}$ shaped solid floor were reported by Huis In 't Veld et al. (1994) and De Boer et al. (1994). They reported that flushing with 501 of water day ${ }^{-1}$ per cow every 2 hours directly after the scraping action resulted in an emission reduction of 34\% compared to only scraping of the solid floor. Increasing the scraping and flushing frequency to once every hour did not result in a significant higher emission reduction. Emission was reduced to $14 \%$ at a reduced water use to 281 day $^{-1}$ per cow combined with an increased scraping and flushing frequency of once every hour. From this data we may conclude that, contradictory to findings for slatted floors, emission reduction and water use are positively correlated for V-shaped solid floors.

At flushing frequencies mentioned above, flushing will not have had a major effect on the urea hydrolysis process through dilution of urea, because urea is usually hydrolysed within $2 \mathrm{~h}$ after urine deposition on floors. To be effective from that point of view, continuous flushing would have to be operated or the flushing frequency would have to be related to the urination frequency. Both options were for technical reasons not investigated.

\section{Slowing down urea hydrolysis}

Slowing down the urea hydrolysis process can be achieved through temperature reduction or inhibition of the enzyme urease. For dairy cow buildings, data on cooling of floor and slurry surfaces and effects on $\mathrm{NH}_{3}$ emission were lacking in literature. Urease inhibitors are well known in rice production (Keerthisinghe \& Freney, 1994) 
and are sometimes used to lower $\mathrm{NH}_{3}$ emissions from feedlots (Varel, 1996). Their applicability in cow buildings has not been investigated. Emission reduction data were obtained from experiments on flushing floors with diluted formaldehyde. Scraping and flushing were combined and conducted hourly and every two hours, respectively. Ammonia emission reduction for slatted floors and V-shaped solid floors, relative to the emission from a cubicle house with slats, was 50\% (Ogink \& Kroodsma, 1996) and 87\% (Bleijenberg et al., 1995), respectively, using daily volumes of 191 and 341 of a diluted formaldehyde solution per cow. These data indicate that urea hydrolysis had been reduced to very low values. Furthermore, Ketelaars \& Rap (1994) successfully removed floor-bound urease activity in dairy-cow houses by rinsing the floor with a hydrochloric acid solution, consequently reducing $\mathrm{NH}_{3}$ emission to very low values.

\section{Control of $p H$}

Lowering the $\mathrm{pH}$ at the emitting surfaces (floor, slurry in the pit) by addition of acid has shown to be quite effective in reducing $\mathrm{NH}_{3}$ emissions from slurry. A reduction of $37 \%$ was reported by Bleijenberg et al. (1995) in experiments where $\mathrm{pH}$ of the slurry, stored in a pit under the slatted floor, was reduced to 4-4.5 by regular addition of nitric acid. Even higher reductions of up to $60 \%$ were achieved by a combination of acidification of slurry in a shallow pit and regular flushing of the slats with the acidified slurry (Kroodsma \& Ogink, 1997).

\section{Reduction of mass transfer}

Possibilities for influencing convective mass transfer of $\mathrm{NH}_{3}$ are through reduction of temperature and air velocity at the emitting surfaces (floor and slurry) and of the area of the emitting surface (Elzing \& Monteny, 1997b). Findings with temperature reduction are previously described. Influencing air velocity in naturally ventilated cow buildings is hard to achieve, because a system for regulation of the ventilation rate is not present or not operated. Except through solid floors, possibly leading to a reduction of air velocity in the pit (see next sub-paragraph), reduction of air velocities by climatisation is therefore not regarded to be a practical option for emission abatement.

Reduction of the area of floors and pit is only possible when the housing system is changed. Ammonia emission was reduced by approximately $10 \%$ when the fouled floor area per cow was reduced from 3.5 to $2.5 \mathrm{~m}^{2}$ in an adapted design for a dairy cow house with cubicles (Metz et al., 1995). For a tie stall with a fouled floor area of approximately $1 \mathrm{~m}^{2}$ per cow and a reduced pit area, emission reduction was $28 \%$ compared to a cubicle house (Metz et al., 1995).

\section{Reduction of air exchange between pit and house}

The area for air exchange between the pit and the air inside the house depends on the floor type used (Braam et al., 1997a) and by parameters causing air exchange (e.g. 
ventilation system, stack effect due to temperature gradients between slurry and inside air; see e.g. Bruce, 1975). For slatted floors, this area is approximately 20-25\% of the total floor area (Anonymous, 1989). In cow buildings equipped with solid floors, the only possibility for air exchange is through the openings at each end of the alleys through which scraped slurry is deposited in the pit. Intermediate openings might be required at increased floor length. The reduced air exchange is an important factor in the emission reduction found for these type of floors relative to slatted floors. As a consequence of reduced air exchange, transport of $\mathrm{NH}_{3}$ volatilised to the air inside the pit to the air inside the house is hindered (Braam et al.,1997b). Furthermore, it might also cause lower air velocities at slurry level, leading to a lower volatilisation (Elzing \& Monteny, 1997b). Also the enhanced accumulation of $\mathrm{NH}_{3}$ in the air inside the pit may contribute to a reduced volatilisation. Swierstra et al. (1995) reported emission reductions between $48 \%$ and $52 \%$ for solid, V-shaped floors. Similar reductions were found by Braam \& Van den Hoorn (1996), for the same floor but with high slurry level and a wooden construction to prevent airflow in the pit. Comparability of those data is hard, because of differences in experimental conditions (season, year).

Table 2 presents a schematic overview of the interaction between $\mathrm{NH}_{3}$ emission reducing measures and processes and parameters. In this overview, emission reduction potential is expressed relative to dairy cow buildings with cubicles, slatted floors and under floor slurry storage.

\section{Prospects of different emission reducing measures}

\section{Nutrition}

Practical possibility for reduction of the nitrogen excretion in urine is replacement of a part of the grass silage in the cow's diet by feed stuffs with a low nitrogen content, e.g. maize (Valk et al., 1990; Dewhurst \& Thomas, 1992). However, dairy cow diet manipulation to reduce $\mathrm{NH}_{3}$ emission should focus on lowering the urinary nitrogen concentration in the urine by lowering the $\mathrm{N}$ surpluses in the diet rather than by increasing the volume of urine produced or the frequency of urination (e.g. through the addition of salt; Smits et al., 1997). In that perspective, the intake of water, induced by the amounts of $\mathrm{N}$ and salts in the diet is of importance.

Other possibilities for the reduction of the nitrogen content of the diet are through improved grassland management and grazing. Bussink (1994) showed that reduction of the $\mathrm{N}$ fertilisation rate of grassland resulted in a significantly lower $\mathrm{NH}_{3}$ emission during grazing of dairy cows. This was mainly caused by a reduced excretion of $\mathrm{N}$. Expectedly, feeding of grass silage from the grassland with the reduced fertilisation rate will also reduce $\mathrm{NH}_{3}$ emission in the dairy cow house. However, no data are available to support this. Bussink \& Oenema (1998) calculated that part time grazing during the summer (cows kept inside during night) leads to an increase in $\mathrm{NH}_{3}$ emission on a farm scale by $10 \%$ compared to full time grazing. Because the cows then 
AMMONIA EMISSION FROM DAIRY COW BUILDINGS

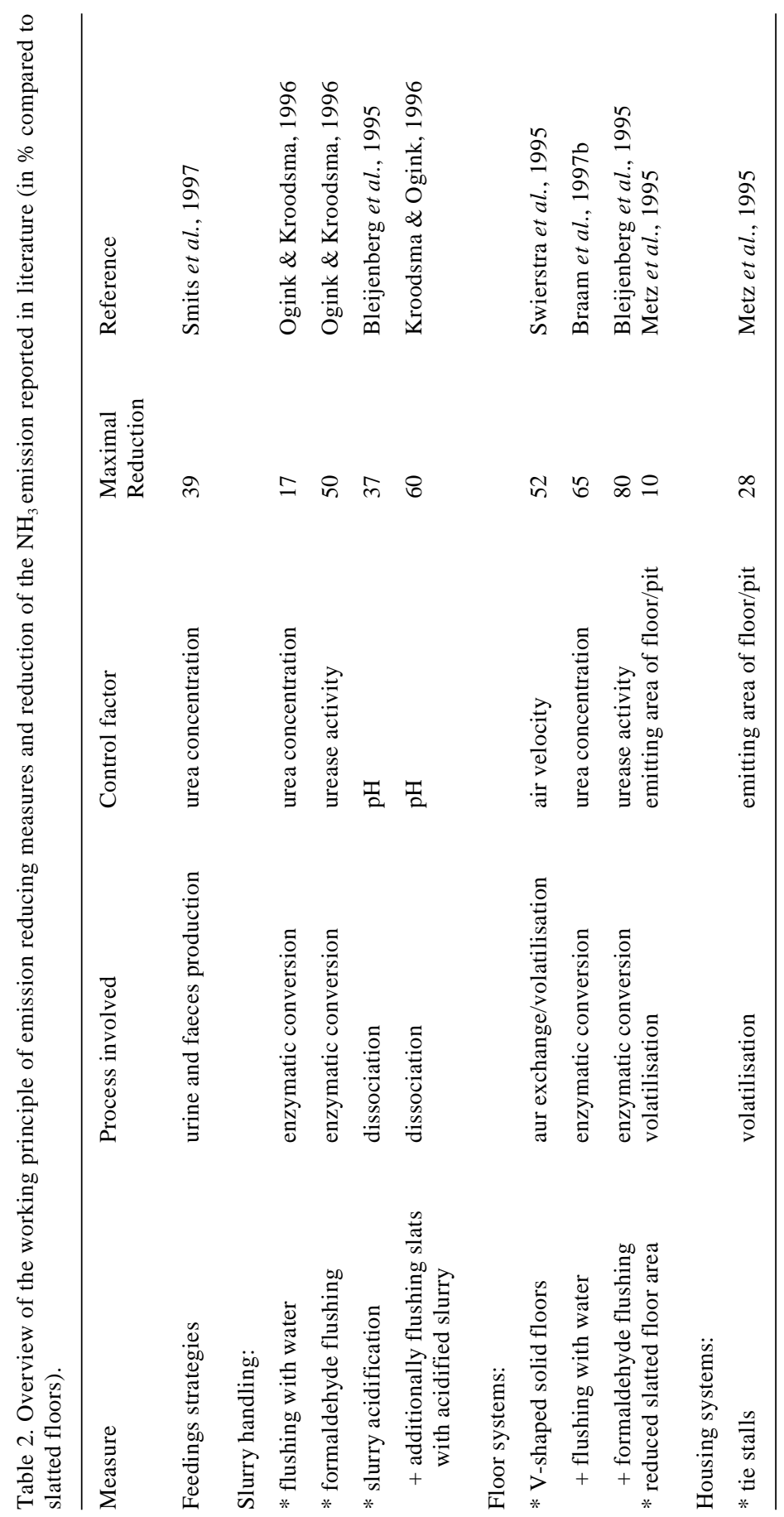


stay inside the house for a longer period of time, more slurry (faeces and urine) is produced inside the house, causing extra emission from the house. Moreover, because more slurry needs to be applied to the field, emission from land spreading increases.

\section{Flushing systems}

A major drawback of flushing is the amount of water added to the slurry. At an average daily slurry production of 501 per cow, flushing of slatted floors would cause and increase in slurry volume of up to $200 \%$. This increase is less pronounced but still considerable for flushing V-shaped solid floors (10-100\%). Besides investment costs for the technology, the storage and application of this extra slurry volume will also lead to additional operational costs. Flushing with diluted formaldehyde solutions allows use of much less water, because the reduced urease activity is more effective than dilution or removal of urine. A disadvantage of the use of formaldehyde is a potential for the emission of formaldehyde gas to the inside air, which might have negative health effects. Safety risks could be minimised when indoor air concentrations can be related to the concentration of formaldehyde in the flushing solutions and when other relevant conditions (e.g. temperature) and limits for concentrations of formaldehyde gas in work-place environment (Ogink \& Kroodsma, 1996) are taken into account.

\section{Control of $p H$}

Reduction of $\mathrm{pH}$ through slurry acidification is an effective way to reduce $\mathrm{NH}_{3}$ emissions. Although different organic and inorganic acids could be used, experiments were only carried out using nitric acid. This was done basically from the point of view of possible substitution of additional chemical fertilisers by slurry mixed with nitric acid. However, due to the risk of denitrification of the nitrate added and consequently the emission of the environmentally harmful $\mathrm{N}_{2} \mathrm{O}, \mathrm{pH}$ had to be kept below 4.5. The amount of nitric acid needed to achieve that $\mathrm{pH}$ value leads to slurry with high nitrogen contents (e.g. around $9 \mathrm{~g} \mathrm{~N} \mathrm{~kg}^{-1}$; Bleijenberg et al., 1995). In order to prevent the risk of extra nitrate leaching when using acidified slurry for (grassland) fertilisation, advanced application technology for small amounts of slurry is required to match $\mathrm{N}$ fertilisation rates with the $\mathrm{N}$ demand of the grassland. Organic or other inorganic acids may be an alternative. However, no literature was found on this relative to dairy husbandry.

\section{Housing systems}

Ammonia emission per cow for tie stalls $\left(5-27 \mathrm{~g} \mathrm{day}^{-1}\right)$ tends to be lower then for loose housing systems with cubicles $\left(25-45 \mathrm{~g}\right.$ day $\left.^{-1}\right)$. The emission reducing effect in tie stalls is mainly caused by a reduction of surface area of the pit and the, urine and faeces fouled, floor. Drawbacks of tie stalls are generally related to a higher labour demand, especially for milking and feeding. Furthermore, new building of tie 
stalls will be forbidden or it is in discussion in some countries (e.g. Switzerland) from the point of view of animal welfare. In that perspective, important topics are freedom of movement for the cows and possibilities to conduct natural behaviour. These requirements are met in systems with loose housing on straw, although $\mathrm{NH}_{3}$ emission for this type of dairy housing (one measurement) might be near cubicle house emission levels. In addition, Groenestein \& Reitsma (1993) found methane emissions of approximately $1 \mathrm{~kg} \mathrm{day}^{-1}$ per cow for these systems. This is substantially higher than average methane emissions from slurry based dairy cow housing systems (0.15-0.37 kg day ${ }^{-1}$ per cow; Crutzen et al., 1986; Van Der Hoek, 1984) and may be related to anoxic degradation processes in the straw bedding. An evaluation of housing systems in the framework of $\mathrm{NH}_{3}$ emission, therefor, needs to be extended with animal welfare and other environmental aspects.

\section{Floor systems}

Compared to slatted floors, longitudinal V-shaped solid floors have a potential for a lower $\mathrm{NH}_{3}$ emission (52\%) as can be concluded from data presented in Table 2. This statement might be questioned when emission data reported for cubicle housing systems equipped with slatted (26-45 $\mathrm{g} \mathrm{day}^{-1}$ per cow) and V-shaped floors ( $25 \mathrm{~g} \mathrm{day}^{-1}$ per cow) are considered (Table 1). However, besides the small number of data present for the comparison, experimental conditions during the measurements reported in Table 1 were different. Slatted floor research was carried out in different countries, in different seasons and under different management conditions, whereas data used for the direct comparison (Table 2) were obtained from an experiment with both floor types under comparable experimental conditions. Braam et al. (1997) and Braam \& Van Den Hoorn (1996) concluded that the design of solid floors and in particular the design and area of openings are important features when it comes to reduction of air exchange and maximisation of emission reduction. In the evaluation of the emission reducing effect of housing systems with $\mathrm{V}$-shaped solid floor, compared to slatted floors, the volume of urine left upon the floor surface after each urination needs to be considered too. Urine volume and urea concentration both determine the amount of urea upon the floor and thus also the potential $\mathrm{NH}_{3}$ production in and emission from the urine puddles upon the floor. Braam \& Van Den Hoorn (1996) reported typical values for both parameters are $0.6 \mathrm{~mm}$ and $0.8 \mathrm{~m}^{2}$ respectively for clean slatted floors, while for V-shaped (3\% slope) solid floors due to draining of urine typical values are $0.15 \mathrm{~mm}$ and $1.2 \mathrm{~m}^{2}$ respectively. This means that the potential $\mathrm{NH}_{3}$ emission for a slatted floor is on average three times higher than for a $\mathrm{V}$ shaped solid floor. Both the reduced potential emission and the reduced air exchange when using solid floors may contribute to the emission reduction reported. A major point of attention when using solid floors in general and inclined solid floors in particular is locomotion of the animals. On an inclined surface cows can easily loose grip which may cause slip incidents and injuries, especially when faeces are not removed thoroughly. Floors with sufficient floor surface texture and roughness may improve that situation (Dumelow \& Albutt, 1988). Furthermore, Braam et al. (1997b) showed that regular wetting of the floor surface could improve faeces re- 
moval and reduce the problems mentioned before.

\section{Synthesis}

Assuming $\mathrm{NH}_{3}$ in dairy cow buildings only originates from urinary urea and $80 \%$ of urinary $\mathrm{N}$ is in the form or urea, potential daily $\mathrm{NH}_{3}$ emission per cow is $65-260 \mathrm{~g}$ ( $80 \%$ of $80-320 \mathrm{~g} \mathrm{~N}$ excreted in urine per cow and per day). Measurements (Table 1) have shown that the actual daily $\mathrm{NH}_{3}$ emission is in the order of magnitude of $30 \mathrm{~g}$ per day, which is $12-46 \%$ of the potential emission. The lower percentage is assumed to be relevant for intensive dairy farming and related high levels of $\mathrm{N}$ input. An important reason for the large difference between actual and potential emission is that at $\mathrm{pH}$ values for urine and slurry, on average 8.5 and 7.5 respectively, only a relatively small percentage of TAN is present in the form of volatile, unionised $\mathrm{NH}_{3}$. Even at reported $\mathrm{pH}$ levels of around 8.6 for urine on the floor and the top layer of slurry in the pit (Elzing \& Monteny, 1997a), much of the TAN will be present as non-volatile $\mathrm{NH}_{4}{ }^{+}$. Beside $\mathrm{pH}$, also other emission determining parameters have to be considered to fully explain the low actual emission relative to the potential emission. Elzing \& Monteny (1997a, 1997b) found that the mass transfer parameters air velocity and temperature highly determine the maximum volatilisation rate per urination, occurring at approximately $2 \mathrm{~h}$ after urine has been deposited on the floor, as well as the duration of the volatilisation process (up to $15 \mathrm{~h}$ or more). At air velocities, temperatures and emitting surface areas found in diary cow buildings, $\mathrm{NH}_{3}$ losses due to mass transfer (volatilisation) will be at a relatively low level when compared to $\mathrm{NH}_{3}$ production in the liquid following urea hydrolysis. Furthermore, each urine pool upon the floor will be refreshed within $10 \mathrm{~h}$ at an average urination frequency per cow of 11 day $^{-1}$ (Whitehead, 1995), a floor area of $0.8 \mathrm{~m}^{2}$ covered by one urination, an available floor area per cow of $3.5 \mathrm{~m}^{2}$ and random distribution of urinations over the available floor area (Monteny et al., 1998). The volatilisation process of the original urine pool will therefor never run to completion.

Agricultural $\mathrm{NH}_{3}$ emission originates for $53 \%$ and $60 \%$ from cattle husbandry in Europe and The Netherlands, respectively (Asman, 1995; Anonymous, 1996). Pig and poultry husbandry is responsible for the remainder. When Dutch emission reduction goals (70\% in 2005 relative to 1980) would be applied on a European scale, $\mathrm{NH}_{3}$ emissions from all sources (land spreading slurry, buildings, storages, grazing) would have to be substantially reduced to achieve them.

New techniques for slurry application and covering of outside slurry storages are already law enforced in The Netherlands since the late 80's. They are applied on a large scale nowadays. As a consequence, the national $\mathrm{NH}_{3}$ emission reduction was calculated to be approximately 69 kton (34\%) in 1995 compared to 1980 (Anonymous, 1996). The contribution of cattle housing and storage systems to the total $\mathrm{NH}_{3}$ emission in The Netherlands was estimated at 45 kton in 1995 (Anonymous, 1996). Based upon the number of dairy cows relative to the number of other cattle (Anonymous, 1995), it can be assumed that approximately 80\% (36 kton per year) of this amount originates from dairy cow buildings. Data presented in Table 2 show that 
an $\mathrm{NH}_{3}$ emission reduction of $50 \%$ seems technically feasible. This can be achieved through innovative floor systems, flushing with diluted formaldehyde, and through a combination of feeding strategies and e.g. flushing with water.

Assuming 100\% penetration of these measures in practice, maximal reduction of the $\mathrm{NH}_{3}$ emission on a national scale will be $18 \mathrm{kton}$. This means that the contribution by dairy cow buildings to achieve the government goal in 2005 (an additional annual reduction of 74 kton from 1995 onward; total reduction of 143 kton per year) will be small and a further emission reduction from all agricultural sources will be necessary. Furthermore, annual costs on farm scale of these $\mathrm{NH}_{3}$ emission reducing measures might be significant (Van Scheppingen et al., 1995), although real figures from practice are few.

Emission reduction in animal buildings generally lead to an increase in the nitrogen content of the slurry. This might imply an additional $\mathrm{NH}_{3}$ emission during storage and land spreading. However, when measures are taken to reduce these emissions substantially (covering of storages, low emission land application), the additional emission will be low.

\section{Conclusions}

Accurate measurement of ventilation rates for naturally ventilated animal buildings has become feasible using tracer gas mass balance methods.

Data on the $\mathrm{NH}_{3}$ emission from different types of dairy cow housing systems indicate that variation is large and that emission from tie stalls $\left(5-27 \mathrm{~g} \mathrm{day}^{-1}\right.$ per cow $)$ is generally lower than from loose housing systems $\left(20-45 \mathrm{~g} \mathrm{day}^{-1}\right.$ per cow). Urea concentration in the urine, urease activity, $\mathrm{pH}$, temperature, air velocity and area of emitting surfaces (floor, pit) are influencing parameters for the emission of $\mathrm{NH}_{3}$. Measures to reduce $\mathrm{NH}_{3}$ emission from dairy cow buildings affect one or more of these parameters. Most effective measures are flushing with formaldehyde (reduction of urease activity), introduction of V-shaped solid floors (minimising air exchange between pit and building, and reduction of air velocity in the pit), feeding strategies (lowering or urea concentration in the urine) and slurry acidification $(\mathrm{pH}$ control). Drawbacks of these measures, like the possible volatilisation of formaldehyde gas when flushing floors with diluted formaldehyde, danger of slipping of the cows on V-shaped solid floors and risks of unwanted emissions of methane (straw systems) and nitrous oxide (acidification with nitric acid) will have to be addressed to ensure application in practice. For the Netherlands, maximal emission reduction through implementation of reducing measures in dairy cow buildings is estimated at 18 kton of $\mathrm{NH}_{3}$ per year.

\section{References}

Anonymous, 1989. Reinforced concrete slatted floors in livestock housing systems (In Dutch). NEN 3873.Nederlands Normalisatie-instituut, Delft, 4 pp. 


\section{G.J. MONTENY AND J.W. ERISMAN}

Anonymous, 1994a. Ammonia emissions to air in Western Europe. Technical Report No. 62. European Centre for Ecotoxicology and Toxicology of Chemicals, Brussels, $196 \mathrm{pp}$.

Anonymous, 1994b. The design of dairy cow housing. Report of the CIGR Section II Working Group No. 14 Cattle Housing. ADAS Bridgets Dairy Research Centre, Reading, 56 pp.

Anonymous, 1995. Statistical Year Report 1995 (In Dutch). SDU Uitgeverij, SBS-Publicaties, 's Gravenhage, 580 pp.

Anonymous, 1996. Environmental balance 96 (In Dutch). Samsom H.D. Tjeenk Willink bv, Alphen a/d Rijn, 142 pp.

ApSimson, H.M., M. Kruse \& J.N.B. Bell, 1987. Ammonia emissions and their role in acid deposition. Atmospheric Environment 21: 1939-1946.

Arogo, J., D.L. Day, L.L. Christianson, G.L. Riskowski \& R. Zhang, 1996. Evaluation of mass transfer coefficient of ammonia from liquid swine manure. In: Heber et al. (Eds.), Proceedings of the First International Conference on Air Pollution from Agricultural Operations. MidWest Plan Service, Ames, pp. 111-118.

Asman, W.A.H., B. Drukker \& A.J. Janssen, 1988. Modelled historical concentrations and depositions of ammonia and ammonium in Europe. Atmospheric Environment 22: 725-735.

Asman, W.A.H., 1995. Ammonia and ammonium in the atmosphere: Present knowledge and recommendations for further research. In: G.J. Heij \& J.W. Erisman (Eds.), Acid rain research: Do we have enough answers? Elsevier Science B.V., Amsterdam, pp. 55-70.

Bleijenberg, R., W. Kroodsma \& N.W.M. Ogink, 1995. Techniques for the reduction of ammonia emission from a cubicle house with slatted floor (In Dutch). Report 94-35, Institute of Agricultural and Environmental Engineering, Wageningen, $34 \mathrm{pp}$.

Braam, C.R. \& C.J. Van Den Hoorn, 1996. Concrete floors for animal houses with low ammonia emission. Results of experimental and applied research (In Dutch). Report 1996-12, Institute of Agricultural and Environmental Engineering, Wageningen, $207 \mathrm{pp}$.

Braam, C.R., J.J.M.H. Ketelaars \& M.C.J. Smits, 1997a. Effects of floor design and floor cleaning on ammonia emission from cubicle houses for dairy cows. Netherlands Journal of Agricultural Science 45: 49-64.

Braam, C.R., M.C.J. Smits, H. Gunnink \& D. Swierstra, 1997b. Effects of water spraying, draining distance of urine, air flow and air exchange on ammonia emission from a sloping floor in a cubicle house for dairy cows. Submitted to Journal of Agricultural Engineering Research.

Bruce, J.M., 1975. Air movement through perforated floors. Farm Building R\&D Studies 5. Scottish Farm Buildings Investigation Unit, Aberdeen, pp. 3-10.

Bussink, D.W., 1994. Relationship between ammonia volatilization and nitrogen fertilizer application rate, intake and excretion of herbage nitrogen by cattle on grazed swards. Fertilizer Research 38 111-121.

Bussink, D.W. \& O. Oenema, 1998. Ammonia volatilization from dairy farming systems in temperate areas; a review. Nutrient Cycling in Agroecosystems (In press).

Collins, W.H. \& J.H. Wilson, 1994. Structurally self-cleaned free stall arrangements. In: R. Bucklin (Ed.), Dairy Systems for the $21^{\text {st }}$ Century. American Society of Agricultural Engineers, St. Joseph, pp. 288-296.

Crutzen, P.J., I. Aselmann \& W. Seiler, 1986. Methane production by domestic animals, wild ruminants, other herbivores fauna, and humans. Tellus 38B: 271-284.

De Boer, W.J., 1993. Box-Jenkins time series analyses applied on measurements of the ammonia emissionin a dairy cow house (In Dutch). Report 93-6, Institute of Agricultural and Environmental Engineering, Wageningen, $37 \mathrm{pp}$.

De Boer, W.J., A. Keen \& G.J. Monteny, 1994. The effect of flushing on the ammonia emission from dairy cattle houses; estimation of treatment effects and accuracies by time series analysis (In Dutch). Report 94-6, Institute of Agricultural and Environmental Engineering, Wageningen, 34 pp.

Bristow, A.W., D.C. Whitehead \& J.E. Cockburn, 1992. Nitrogeneous constituents in the urine of cattle, sheep and goats. Journal of Science in Food and Agriculture 59: 387-394.

Demmers, T.G.M., L.R. Burgess, J.L. Short, V.R. Phillips, J.A. Clark, J.A. \& C.M. Wathers, 1998. First experiences with methods to measure ammonia emissions from naturally ventilated cattle buildings in the UK. Atmospheric Environment (in press).

Dewhurst, R.J. \& C. Thomas, 1992. Modeling of nitrogen transactions in the dairy cow and their envi- 
ronmental consequences. Livestock Production Science 31: p. 1-16.

Dumelow, J. \& R. Albutt, 1988. Developing improved designs of skid-resistant floors for dairy cattle buildings. In: Anonymous (Ed.), Livestock Environment III. ASAE-publication 1088. American Society of Agricultural Engineers, St. Joseph, pp. 163-170.

Elzing, A. \& G.J. Monteny, 1997a. Modeling and experimental determination of ammonia emission rates from a scale model dairy-cow house. Transactions of the ASAE 40: 721-726.

Elzing, A. \& G.J. Monteny, 1997b. Ammonia emission from a scale model of a dairy-cow house Transactions of the ASAE 40: 713-720.

Erisman, J.W. \& A. Bleeker, 1997. Emission concentration and deposition of acidifying substances. In: G.J. Hey \& J.W. Erisman (Eds.) Studies in Environmental Research 69, Elsevier, Amsterdam, p. 21-82.

Fulhage, C. \& J.G. Martin III, 1994. Dairy waste flushing. In: R. Bucklin (Ed.). Dairy Systems for the $21^{\text {st }}$ Century. American Society of Agricultural Engineers, St. Joseph, pp. 704-714.

Graves, R.E., D.J. Meyer \& G.A. Shirk, 1994. Gravity manure handling inside and outside the tie stall barn. ASAE paper no. 84-4064. American Society of Agricultural Engineers, St. Joseph, 14 pp.

Groenestein, C.M. \& H. Montsma, 1991. Field research into the ammonia emission from animal housing systems: Tying stall for dairy cattle (In Dutch). Report 91-1002, Agricultural Research Department, Wageningen, 14 p. (excl. appendices).

Groenestein, C.M. \& B. Reitsma, 1993. Field research into the ammonia emission from animal housing systems XV: Straw bed housing for dairy cows (In Dutch). Report 93-1005, Agricultural Research Department, Wageningen, 15 p. (excl. appendices).

Groot Koerkamp, P.W.G. \& A. Elzing 1996. Degradation of nitrogenous components in and volatilization of ammonia from litter in aviary housing systems for laying hens. Transactions of the ASAE 39: $211-218$

Groot Koerkamp, P.W.G., G.H. Uenk, J.H.M. Metz, V.R. Phillips, M.R. Holden, R.W. Sneath, J.L. Short, R.P. White, J. Hartung, J. Seedorf, M. Schroeder, K.H. Linkert, H. Takai, S. Pedersen, J.O. Johnsen \& C.M. Wathes, 1998 Concentrations in and emissions of ammonia from livestock buildings in Northern Europe. Journal of Agricultural Engineering Research (in press).

Hashimoto, A.G., 1972. Ammonia desorption from concentrated chicken manure slurries. PhD Thesis Cornell University, Ithaca, 224 pp.

Haslam, R.T., R.L. Hershey \& R.H. Keen, 1924. Effect of gas velocity and temperature on rate of absorption. Industrial and Engineering Chemistry 16: 1224-1230.

Heij, G.J. \& J.W. Erisman (Eds.), 1997. Acid atmospheric deposition and its effects on terrestrial ecosystems in the Netherlands. The third and final phase (1991-1995). Studies in Environmental Science 69, Elsevier, Amsterdam, 705 pp.

Heij, G.J.\& T. Schneider, 1991. Acidification research in the Netherlands. Studies in Environmental Science 46, Elsevier, Amsterdam, 771 pp.

Huis In 't Veld, J.W.H., W. Kroodsma \& W.J. De Boer, 1994. Reduction of ammonia emission from a cubicle house by flushing a sloped concrete floor (In Dutch). Report 94-4, Institute of Agricultural and Environmental Engineering, Wageningen, 24 pp.

Keerthisinghe, D.G. \& J.R. Freney, 1994. Inhibition of urease activity in flooded soils: effect of thiophosphorictriamides and phosphorictriamides. Soil Biology Biochemistry 26: 1527-1533.

Ketelaars, J.J.M.H. \& H. Rap, 1994. Ammonia volatilization from urine applied to the floor of a dairy cow barn. In: L. 't Mannetje \& J. Frame (Eds.), Grassland and Society. Wageningen Press, Wageningen, pp. 413-417.

Kroodsma, W., J.W.H. Huis In 't Veld \& R. Scholtens, 1993. Ammonia emissions and its reduction from cubicle houses by flushing. Livestock Production Science 35: 293-302.

Kroodsma, W. \& N.W.M. Ogink, 1997. Volatile emission from cow cubicle houses and its reduction by slurry acidification and immersion of the slats with acidified slurry. In: J.A.M. Voermans \& G.J. Monteny (Eds.) Ammonia and Odour Control from Animal Production Facilities. Research Institute for Pig Husbandry (PV), Rosmalen, pp 475-483.

Loehr, R.C., 1973. Development and demonstration of nutrient removal from animal wastes. U.S. Government Printing Office, Washington D.C., 139 pp.

Mannebeck, H. \& J. Oldenburg, 1990. Comparison of the effects of different systems on ammonia emission. In: V.C. Nielsen, J.H. Voorburg \& P. L'Hermite (Eds.), Odour and Ammonia Emissions from 


\section{G.J. MONTENY AND J.W. ERISMAN}

Livestock Farming. Elseviers Applied Science, Londen/New York, pp. 42-49.

Metz, J.H.M., N.W.M. Ogink \& M.C.J. Smits, 1995. Research on housing systems and manure treatment to reduce ammonia emission in dairy husbandry. In: W. Luten, H. Snoek, S. Schukking \& M. Verboon (Eds.), Applied Research for Sustainable Dairy Farming. Research Station for Cattle, Sheep and Horse Husbandry (PR), Lelystad, pp. 36-39.

Monteny, G.J., D.D. Schulte, A. Elzing \& E.J.J. Lamaker, 1998. A conceptual mechanistic model for the ammonia emission from cubicle dairy cow houses. Transactions of the ASAE 41(1): 193-201.

Moore, J.A. \& R.O. Hegg, 1980. Effects of rations on beef cattle manure handling characteristics on solid and slatted floor. Transactions of the ASAE 23: 423-426.

Muck, R.E. \& T.S. Steenhuis, 1981. Nitrogen losses in free stall dairy barns. In: Anonymous (Ed.) LivestockWastes: A Renewable Source. American Society of Agricultural Engineers, St. Joseph, pp. 406-409.

Muck, R.E. \& T.S. Steenhuis, 1982. Nitrogen losses from manure storages. Agricultural Wastes 4: 41-54.

Ogink, N.W.M. \& W. Kroodsma, 1996. Reduction of ammonia emission from a cow cubicle house by flushing with water or a formalin solution. Journal of Agricultural Engineering Research 63: 197-204.

Patni, N.K. \& P.Y. Jui, 1991. Nitrogen concentration variability in dairy-cattle slurry stored in farm tanks. Transactions of the ASAE 34: 609-615.

Pfeiffer, A., F. Arends, G. Steffens \& H.J. Langholz, 1994. Ammonia emissions originating from naturally ventilated dairy cow housing systems with different dung systems. In: J.E. Hall (Ed.), Anima Waste Management. Technical Series 34. Food and Agriculture Organization of the United Nations, Rome, pp. 39-44.

Scholtens, R., J.J.C. Van der Heiden-de Vos, J.J.C. \& J.W.H. Huis In 't Veld, 1996. Validation of gas balance models for determining ventilation rates of dairy cattle houses (In Dutch). Report 96-11, Institute of Agricultural and Environmental Engineering Wageningen, 24 pp. (excluding technical annex).

Smits, M.C.J., H. Valk, H., A. Elzing \& A. Keen, 1995. Effect of protein nutrition on ammonia emission from a cubicle house for dairy cattle. Livestock Production Science 44: 147-156.

Smits, M.C.J., A.M. Van Vuuren \& M.C. Verboon, 1996. Research into urine production, urination pattern and ammonia emission for dairy cows (In Dutch). In: P. Van der Aar, A.J.A. Aarnink, M.C. Blok \& M. Van Vuuren (Eds.), Animal Nutrition and Ammonia Emission: State of the Art in Research. Kwaliteitsreeks (VVr) nr. 37. FOMA \& Productschap voor Veevoeder, Wageningen/Den Haag, pp 65-87.

Smits, M.C.J., H. Valk, G.J. Monteny \& A.M. Van Vuuren, 1997. Effect of protein nutrition on ammoniaemission from cow houses. In: S.C. Jarvis \& B.F. Pain (Eds.), Gaseous Nitrogen Emissions from Grasslands, CAB International, Wallingford, pp. 101-107.

Svensson, L. \&M. Ferm, 1993. Mass transfer coefficient and equilibrium concentration as key factors in a new approach to estimate ammonia emission from livestock manure. Journal of Agricultural Engineering Research 56: 1-11.

Swierstra, D., M.C.J. Smits \& W. Kroodsma, 1995. Ammonia emission from cubicle houses for cattle with slatted and solid floors. Journal of Agricultural Engineering Research 62: 127-132.

Tamminga, S., 1992. Nutrition management of dairy cows as a contribution to pollution control. Journal of Dairy Science 75: 345-357.

Valk, H., H.W. Klein Poelhuis \& H.J. Wentink, 1990. Effect of fibrous and starchy carbohydrates inconcentrates as supplements in a herbage-based diet for high yielding dairy cows. Netherlands Journal of Agricultural Science 38: 475-486.

Van Der Hoek, K.W., 1984. Methane production and utilization on cattle farms. Summary of multidisciplinairy research project 1980-1983 (In Dutch). Publication 203, Institute of Agricultural and Environmental Engineering, Wageningen, $36 \mathrm{pp}$.

Van Ouwerkerk, E.N.J. (Ed.), 1993. Methods for measuring ammonia emission from livestock building (In Dutch). Report 16, Agricultural Research Department, Wageningen, 178 pp.

Van Ouwerkerk, E.N.J. \& S. Pedersen, 1994. Application of the carbon dioxide mass balance method to evaluate ventilation rates in livestock buildings. In: Anonymous (Ed.), XII World Congress on Agricultural Engineering, International Society of Agricultural Engineers (CIGR), Merelbeke, pp. $516-529$ 
Van 't Klooster, C.E., R. Scholtens, R. \& J.A.M. Voermans, 1996. Measurement strategies and techniques for indoor air quality in livestock buildings in the Netherlands. In: A. Heber (Ed.). Proceedings on the International Conference on Air Pollution from Agricultural Operations. Midwest Plan Service, Ames, pp. 193-200.

Van 't Ooster, A, 1994. Using natural ventilation theory and dynamic heat balance modelling for real time prediction of ventilation rates in naturally ventilated livestock houses. In: Anonymous (Ed.), XII World Congress on Agricultural Engineering, International Society of Agricultural Engineers (CIGR), Merelbeke, pp. 1-12.

Van Scheppingen, A.T.J., S.J.F. Antuma \& F. Mandersloot, 1995. Economic effects of strategies to reduce nitrogen and phosphorus surpluses. In: W. Luten, H. Snoek, S. Schukking \& M. Verboon (Eds.), Applied Research for Sustainable Dairy Farming. Research Station for Cattle Sheep and Horse Husbandry (PR), Lelystad, pp. 36-39.

Van Vuuren, A.M., C.J. Van der Koelen C.J., H. Valk \& H. De Visser, 1993. Effects of partial replacement of ryegrass by low protein feeds on rumen fermentation and nitrogen loss by dairy cows. Journal of Dairy Science 76: 2982-2993.

Van Vuuren, A.M. \& M.C.J. Smits, 1997. Effect of nitrogen and sodium chloride intake on production and composition of urine in dairy cows. In: S.C. Jarvis \& B.F. Pain (Eds.), Gaseous Nitrogen Emissions from Grasslands, CAB International, Okehampton (in press).

Varel, V.H., 1996. Effect of urease inhibitors on reducing ammonia emissions in cattle waste. In: A. Heber (Ed.), Proceedings of the International Conference on Air Pollution from Agricultural Operations. Midwest Plan Service, Ames, pp. 459-465.

Weast, R.C., J.J. Astle \& W.H. Beyer, 1986. Handbook of Chemistry and Physics, 67th Edition. CRC Press, Boca Raton, Florida, A1-I36 pp.

Whitehead, D.C., 1995. Grassland nitrogen. CAB International, Wallingford, 397 pp.

Wyers, G.P., R.P. Otjes \& J. Slanina, 1993. A continuous-flow denuder for the measurement of ambient concentrations and surface-exchange fluxes of ammonia. Atmospheric Environment 27A: 2085-2090. 
